\title{
STUDY FENOMENOLOGI DISFUNGSI SEKSUAL PADA PRIA DIABETES MELLITUS
}

\author{
Hasbullah $^{1)}$, Alamsyah ${ }^{2)}$, Samsir $^{3)}$ \\ 1 Akademi Keperawatan Pelamonia Makassar \\ email: hasbullahnurse@gmail.com \\ 2 Akademi Keperawatan Pelamonia Makassar \\ email: alamkperpelamonia@Gmail.com \\ ${ }^{3}$ Akademi Keperawatan Pelamonia Makassar \\ email: samsir.syam1990@gmail.com
}

\begin{abstract}
Diabetes mellitus as a metabolic disease plays a very important role in a person's sexual identity and physical capacity to carry out sexual activities, this is because the whole system will change and affect one's sexual health and this requires comprehensive treatment.

This research aims to: explore in-depth information about Sexual Dysfunction in Diabetes Mellitus Men in Makassar Grestelina Hospital.

This type of research is qualitative with a phenomenological study approach that is the method of observation, in-depth interviews, and documentation. There were 7 informants with noncomplication type 2 Diabetes mellitus criteria, GDS $\geq 200 \mathrm{mg} / \mathrm{dl}$ and $G D P \geq 140 \mathrm{mg} / \mathrm{dl}$.

The results obtained informants who experience lack of desire / libido less arousal, mood as much as 5 informants, who do not experience disruption / libido as much as 2 informants, while those who suffer from premature ejaculation as many as 5 informants and not premature ejaculation as many as 2 informants and who experience erectile dysfunction do not a maximum of 2 informants, 4 weak informants quickly, difficult to erect 1 informant. This means that sexual dysfunction such as desire I libido, premature ejaculation and erectile dysfunction occur in early diabetes mellitus patients as assessed from interviews with research informants.

Conclusions when increasing blood sugar levels or insulin resistance can inhibit the flow of uric acid blood vessels so that it can affect sexual problems and sexual dysfunction.

It is recommended that all people with diabetes mellitus are expected to conduct a comprehensive health check, control blood sugar at the same time and pay attention to a healthy lifestyle, regulate diet and exercise.
\end{abstract}

Keywords: Sexual dysfunction, Diabetes Mellitus

\section{PENDAHULUAN}

Diabetes mellitus sebagai penyakit metabolik sangat berperan dalam identitas seksual dan kemanpuan fisik seseorang untuk melaksanakan aktifitas seks, hal ini dikarenakan seluru sistem akan berubah dan mempengaruhi kesehatan seksual seseorang, dan ini membutuhkan penanganan yang holistik dan terintegrasi. Pada kenyataannya, masalah seksual sangat sensitive untuk dibicarakan dan membutuhkan pendekatan dengan baik dan mempertimbangkan privasi serta kerahasiaan klien.

Diabetes mellitus merupakan penyakit degenerative yang memerlukan upaya penanganan yang tepat dan serius. Jika tidak diatasi, diabetes mellitus akan menimbulkan berbagai komplikasi serius lainnya seperti penyakit jantung, stroke, disfungsi ereksi, gagal ginjal dan kerusakan sistem saraf oleh kararena itu diabetes mellitus merupakan salah satu ancaman terbesar bagi kesehatan manusia (Widyanto, 2013).

Diabetes diketahui sebagai penyebab berbagai masalah medis, psikologis dan seksual. Kegagalan fungsi seksual (disfungsi seksual) pada laki-laki sering ditemukan sebagai komplikasi diabetes lanjut. Pada laki-laki 
disfungsi seksual ini dapat berupa menurunnya libido

(kegairahan/dorongan/ketertarikan seksual) dan disfungsi ereksi atau kesulitan ereksi (Rusell, 2014).

Pria menderita diabetes mellitus dengan kadar gula yang tidak terkontrol akan merusak sistem vaskuler dan syaraf. Kerusakan vaskuler akan mengurangi dan menghambat aliran darah sehingga terjadi disfungsi reflex endotel pada pembuluh darah, termaksuk didalamnya adalah kurangnya aliran darah kepenis yang mengakibatkan disfungsi ereksi (Waldinger, 2008).

Seks merupakan bagian penting dari hubungan manusia dewasa. Tidak terpenuhinya kebutuhan seks dapat menimbulkan rasa bersalah dan penolakan sehingga menyebabkan permasalahan dalam pola berhubungan pasangan. Berdasarkan data dari sexual dysfunction Association ( 2009) yang dilansir oleh (Philip \& Khan 2010), masalah seksual dapat terjadi pada sekitar wanita $50 \%$ dan pada pria $>50 \%$ pada penderita disfungsi seksual yang dialami antara lain gangguan hasrat seksual, disfungsi ereksi, ejakulasi dini, gangguan orgasme.

Berdasarakan Data yang diperoleh Rumah Sakit Grestelina Makassar pada tahun 2013 di dapatkan data dari Rekam Medik bahwa pada tahun 2014 sebanyak 250 orang, tahun 2015 sebanyak 570 orang, tahun 2014 sebanyak 456 orang dan pada tahun 2016 meningkat menjadi 480 orang.

Disfungsi ereksi pada penderita Deabetes mellitus merupakan komplikasi yang terabaikan. Hal ini terjadi karena adanya faktor psikosial yang juga berperan pada fungsi seksual. Selain itu, adanya konsep bahwa disfungsi ereksi merupakan akibat dari proses penuaan juga menyebabkan hal ini sering diabaikan oleh dokter ditambah lagi, pengaruh sosial dan budaya yang berkembang di masyarakat menyebabkan seksualitas menjadi suatu hal yang tabu untuk diperbincangkan (Lim KB, 2006) .

\section{METODE}

Desain penelitian yang digunakan adalah penelitian kualitatif dengan pendekatan study fenomenologi, sampel dalam penelitian ini sebanyak 7 orang informan yang dipilih secara purposive sampling Sebagai penelitian kulitatif maka hasil wawancara mendalam indepth interview akan dijabarkan sebagai informasi kemudian memberikan makna dari informasi tersebut melalui analisis data, dilaksanakan selama 60 menit diruang perawatan intena di rumah sakit Grestelina Makassar berisi pertanyaan, panduan wawacara mendalam informan, perekaman suara dan catatan.

\section{HASIL DAN PEMBAHASAN}

\section{HASIL}

Dari 7 informan dalam penelitian ini lakilaki, dengan status pekerjaan yang berbeda-beda yaitu Tn.J, usia 60 tahun, wiraswasta, Tn. A, umur 50 tahun, Suwasta, Tn. K, umur 55 tahun, Tn. S, umur 45 tahun, suwasta, Tn.F, umur 53 tahun, PNS, Tn.B, umur 40 tahun, Wiraswata, Tn. R, umur 47 tahun, PNS .Status pernikahan menikah. Dari Hasil wawancara teridentifikasi 3 tema yaitu:

a. Hasrat/Libido

Pada informan menyatakan bahwa:

$$
\begin{aligned}
& \text { "Awal saya sakit gula mulai mi } \\
& \text { rasa gairaku kurang, saat ini } \\
& \text { hampir tidak ada", }
\end{aligned}
$$

(Tn. J Umur 60 Tahun)

Dari hasil wawancara informan mengatakan bahwa awal terjadinya diabetes mellitus hasrat seksual menurun dan hampir tidak ada hasrat/libido. Selanjutnya informa mengugkapaka bahwa sudah 1 tahun merasakan.

"Kalau saya ingat sekitar 1
tahun merasakan malas secara
perlahan-lahan merasakan
malas"

( Tn. A Umur 50 Tahun)

Dari hasil wawancara informan mengatakan bahwa sekitar 1 tahun hasrat seksual perlahanlahan menurun. Selanjutnya Tn. K merasakan malas dan nafsu kurang.

\section{'Kadang-kadang saya rasa malas berhubungan inti sama istri karna nafsu kurang",}

(Tn. K. Umur 55 Tahun) 
Dari hasil wawancara informan mengatakan bahwa hasrat seksual kurang. Selanjutnya ungkapan Tn.S nafsu kurang dan melakukan hubungan seksual juga menurun.

Kurang mi juga nafsuku tidak gairah ma kurasa mau berhubungan sama istriku, Saya melakukan hubungan suami istri sudah 2 kali dalam 3 minngu itu cukupmi kurasa,

(Tn.S. Umur 45 Tahun)

Dari hasil wawancara informan mengatakan bahwa mengalami hasrat/libido menurun. sedangkan informan seanjutnya mengungkapakan bahwa:

'Nafsu adaji, skarang cepak-capekma tiadak rutin ma main sama istriku kadang juga nonton film forno hibur diri. Waktu belum sakit kencing manis bira 2 kali seminggu sangup ja tapi selama sakit gula 1 kali mami dalam 1 bulan"

\section{(Tn. F Umur 40 Tahun)}

Dari hasil wawancara informan mengatakan bahwa mudah lelah sehingga tidak ada hasrat untuk berhubungan seksual dan mengalami penurunan frekuensi hubungan seksual, informan berhubungan inti hanya 1 kali dalam sebulan, ideal hubungan seksual 1-4 kali dalam seminggu. sejalan apa yang dirasakan

\section{'kalau dibilang mau main sama istri kurang mi kurasa secara perlahan- lahan sejak muali ka sakit gula di umur 33 tahun mungkin kapan gulaku tidak di kontrol jadi begitimi kapan. 'Melakukan bukanlah berkurang tapi sudah satu bulan lebih tidak berhubungan sama istri",}

(Tn.B Umur 40 tahun)

Dari hasil wawancara informan mengatakan bahwa mengalami penurunan hasrat/libido secara perlahan-lahan. sehingga hubungan seksual hanya 1 kali dalam sebulan. pada Informan selanjutnya selama didagnosa diabetes mellitus mulai merasakan hasrat seksual menurun.
'Lamami kurasa malas-malasmi berdiri sejak sakit kurasa. Waktu saya berhubungan dengan istri tidak keluar cairan mani saya hampir 1 bulan baru ada keluar, dalam seminggu tidak. Biasanya keluarpi baru ada rasa puas sedikit, 'Waktu belum bira 2 kali seminggu sangup ja tapi selama sakit gula 1 kali dalam 1 bulan, kalu kontrol kedokter tidak teratur kadang 2 sebulan",

(Tn. R Umur 47 tahun)

Dari hasil wawancara informan mengatakan bahwa sudah 2 tahun mengalami hasrat/libido menurun, tidak dapat ejakulasi, dan tidak rutin control kedoter.

b. Ejakulai dini

Berdasarkan hasil wawancara mengenai gangguan ejakulasi dini pada informan menyatakan bahwa:

,'Waktu saya berhubungan
dengan istri tidak keluar cairan
mani saya hampir 2 bulan
baru,ada keluar, dalam seminggu
tidak. Biasanya keluarpi baru ada
rasa puas begitu aku alami,"

(Tn.J Umur 60 tahun)

Dari hasil wawancara informan bahwa pada saat hubungan inti dengan pasangan tidak mengalami ejakulasi, sedangkan informan Tn. A merasa ejakulasi dini

"Kalau saya dek, ta sebentar
sekali mija keluarmi semenjak
sakit gula kah nah bilang dokter
disitu mi mulai kurasa ada
perubahkan beberapa tahun
kurasa mungkin karna umur mi
juga iyya dek",

(Tn.A Umur 50 tahun)

Dari hasil wawancara informan menyatakan bahwa ketika melakukan hubungan seksual cepat mengalami ejakulsi dini. Informan selanjutnya mengungkapakan yang sama bahwa pada saat melakukan hubungan seksual cepat ejakulasi.

"'Awal-awal main sama istri kuat ji, tapi pas baru berapa kali ji goyang 
keluarmi ${ }^{\prime}$

(Tn.K Umur 55 tahun)

Dari hasil wawancara informan menyatakan bahwa awal hubungan seksual masih kuat ketikan melakukan hubungan inti dengan pasangan hanya berapa kali memasukan penis kedalam vagina sudah mengalami ejakulasi. Selanjutnya ungkapan dari informan Tn.S pada saat hubungan seksual hanya 2 menit sudah ejakulasi.
'Semenjak sakitkah gula sering tinggi gulaku dan kalu main sama istriku Itu cairan putih cepat keluar paling 2 menit jie"' dulu sebelum sakit lama sekitar 15-20 menit',

\section{(Tn.S Umur 45 tahun)}

Dari hasil wawancara informan menyatakan bahwa pada saat melakukan hubungan seksual hanya 2 menit sudah mengalami ejakulasi. Selanjutnya informan mengungkapaka bahwa:

'Cepatmi keluarnya waktu saya dikatan kencing manis, kalau kerasmi punya saya tidak lamajie keluar',

(Tn.F Umur 53 tahun)

Dari hasil wawancara informan menyatakan bahwa selama menderita diabetes mellitus ejakulasi cepat dan ereksi tidak lama. Selanjutnya ungkapan informan merasakan bahwa:

\section{'saya begitu cepat berdiri langsung main sama istri tiba-tiba cepat jie juga keluar tidak lama bertahan',}

(Tn.B Umur 40 tahun)

Dari hasil wawancara informan menyatakan bahwa pada saat ereksi langsung melakukan hubungan seksual secara cepat mengalami ejakulai dan tidak lama bertahan sedangkan ungkapan informan Tn.R tidak mengalami ejakulasi.

' Waktu saya berhubungan dengan istri tidak keluar cairan mani saya hampir 2 bulan baru,ada keluar, dalam seminggu tidak. Biasanya keluarpi baru ada rasa puas begitu ku alami',

(Tn.R Umur 47 Tahun)

Dari hasil wawancara inform menyatakan bahwa pada saat melakukan hubungan seksual tidak mengalami ejakulasi dan tidak merasakan puas pada saat berhubungan seksual.

c. Disfungsi ereksi

Berdasarkan hasil wawancara mengenai disfungsi Ereksi tentang terjadinya gangguan pada informan menyatakan bahwa:

'Saya sakit sejak 7 tahun yang lalu kalau tidak salah ingat tahun 2010 lama kemudia baru ada saya rasa ada perubahan, Beberapa bulan ini kurasa dek kaya susa berdiri anauku Seperti ada yang kurang dari Saya, dirangsang dulu, dan selama ini saya merasa keluhan kurang keras kalau berdiri alat kemaluan",

(Tn. J Umur 60 Tahun)

Menurut hasil wawancara diatas informan merasakan adanya gangguan ereksi itu dirasakan sejak didiagnosa diabetes mellitus 7 tahun yang lalu yang. sejalan apa yang dirasakan informan yang lain sebagai berikut :

'Berdiri ji anuku tapi kalau begitumeka sama istriku tidak lama, mauka pertahankan cepat loyo',

(Tn.A Umur 50 Tahun)

Dari hasil wawacara informan adanya masalah gangguan ereksi dan tidak dapat mempertahankan dan cepat lemas. selanjutnya informanTn.K mengungkapkan juga merasakan ereksi tidak lama.

'Iya tidak bertahan lama, tidak seperti dulu waktu mudah lama sekali jie iyya Kalu dibilang lama paling 2 menit bisa bertahan"'

(Tn.K Usia 55 Tahun)

Dari hasil wawancara informan menyatakan bahwa ereksi tidak lama dan paling hanya 2 menit. Selanjutnya pernyataan informan Tn.S ereksi tidak lama dan mudah lelah. 


\section{" Tidak terlalu lama jie karna cepat ma juga capek kalau melakukan hubungan sama istri"}

(Tn. S Umur 45 Tahun)

Dari hasil wawancara informan menyatakan bahwa ereksi tidak lama ketika melakukan hubungan cepak merasakan lelah. Informan mengungkapkan bahwa proses ereksi lama.

\section{“Lama saya tunggu dulu.....paling dirayu rayu sama istri, waktu sebelum sakit biar tidak ada gombalan bertahan ja hehehehe",}

(Tn. F Umur 53 Tahun)

Dari hasil wawancara informan menyatakan bahwa proses ereksi membutuhkan waktu yang lama dan harus diawali (fore play) dengan pasangan. Selanjutnya pernyataan informan Tn. B mengungkapkan bawha merasakan butuh proses ereksi sama yang dialami dengan Tn. F

'Tidak bisa berdiri kemaulan saya, nanti dirangsang sama istri mulai berdiri, 3 minngu terahkir ini belum pernah berdiri karena sakit sepertimi terong",

(Tn.B Umur 40 Tahun)

Dari hasil wawancara informan menyatakan bahwa tidak mampu ereksi tetapi harus dengan (fore play).

\section{PEMBAHASAN}

\section{a. Gangguan Ejakulasi Dini}

Hasil penelitian yang didapatkan dari 2 informan mengatakan tidak ada gangguan hasrat /libido nafsu ini masih tetap ada bahkan masih tinggi namun itu bersifat sementara ketika ada perasaan kecewa dan takut tidak bisa ereksi dan ejakulasi. Hasrat seksual yang dimiliki informan pada dasarnya tetap ada hanya saja hasrat ini ahkirnya hanya sekedar hasrat yang tidak tersalurkan karena kondisi fisik yang dialami terganggu karena meningkatnya gula darah sewaktu, namun berusaha nonton film porno atau membaca artikel tentang seks dorongan keinginan untuk bersenggama, merupakan motivasi besar untuk melewati kehidupan seksualnya. Hal ini sesuai dengan menurut (Mccartthy, 2008) bahwa nafsu bagi pria bukanlah suatu tahap. Ketika seorang berada dikondisi fisik dan kesehatan emosional yang bagus maka dorongan seksual akan terus ada dalam hidup, penurunan kondisi fisik juga menjadi disfungsi seksual yang dialami karena meningkatnya kadar glukosa darah menyebabkan metabolisme yang ahkirnya membuat lelah dan berpengaruh terhadap hasrat dan aktivitas seksual.

Menurut penelitian Untung, 2010 bahwa banyak faktor yang mempengaruhi perubahan hasrat seksual diantaranya pisikis steres. Menurut Koes, 2014 ganggauan metabolisme dalam tubuh seperti pankreas tidak mampu lagi memperduksi insulin sehingga berakibat timbul penyakit kencing manis dan dapat mempengaruhi hasrat/libido.

Berdasarkan hasil penelitian yang didapatkan 5 Informan yang mengalami kurang gairah, mood karena adanya perasaan cemas, malu atau takut karena tidak bisa ereksi dan ejakulasi pada saat mau berhubungan sehingga dapat menyebabkan tertahan nafsu seksual sehingga hubungan seksual menurun karena tidak menyenangkan atas kehidupan seksnya. Gangguan hasrat ini muncul sebagai keluhan sekunder yang dialaminya bukan merupakan gangguan yang berdiri sendiri tampa bisa dihilangkan. Stres yang terus menerus setiap ingin melakukan hubungan intim atau saat hasrat itu ada, karena informan dapat menprediksi bahwa dia tidak dapat mempertahankan ereksi dengan maksimal dan lama ahkirnya terjadi ejakulasi dini sedangkan istri belum merasa kepuasan. Pengalaman seksual yang tidak menyenangkan terjadi pada informan setiap melakukan hubungan intim selalu berfikir tidak manpu tanpa bisa dikendalikan meskipun yakin untuk bisa melalunya sangat tinggi.

Menurut penelitian Untung, 2010 bahwa banyak faktor yang mempengaruhi perubahan hasrat seksual diantaranya pisikis stres. Menurut Koes, 2014 ganggauan metabolisme dalam tubuh seperti pankreas tidak mampu lagi memperduksi insulin sehingga berakibat timbul penyakit kencing manis dan dapat mempengaruhi hasrat/libido. 
Selain faktor menurunnya kadar hormon testosteron sebagai faktor fisik menurunnya libido dapat juga disebabkan menurunnya kadar hormon tiroid, meningkatnya hormon prolaktin, kelelahan karena penyakit kronis, obat-obatan dan juga bisa diakibatkan faktor psikologi seperti rasa bersalah, stres berkepanjangan dan pengalaman seksual yang tidak menyenangkan ( Pangkahila, 2005).

Penelitin memperoleh infromasi bahwa informan mengatakan hasrat seksual sebenarnya masih ada. Hanya saja hasrat ini ahkirnya hanya sekedar hasrat yang tidak tersalurkan karena kondisi fisik yang mengalami penurunan serta disfungsi ereksi dan ejakulasi dini yang dialaminya.

Penelitian Rachamdi (2008), pada uji korelasi yang didapatkan baik kadar gula darah puasa dan kadar gula darah 2 jam PP mempunyai korelasi positif yang signifikan dengan gangguan libido dengan tingka korelasi sedang, artinya semakin tinggi kadar gula darah dalam darah akan diikuti dengan semakin tingginya libido. Pada 26 orang $(65 \%)$ penderita diabetes melitus dengan kadar gula darah puasa diatas 126 $\mathrm{mg} / \mathrm{dl}$ berkecenderungan $8,7 \times$ lebih besar mengalami hambatan libido dibandingkan penderita diabetes mellitus dengan kadar gula darah puasa dibawah $126 \mathrm{mg} / \mathrm{dl}$ yaitu sebanyak 3 orang $(7,5 \%)$. Demikian pula terdapat 27 orang $(67,5 \%)$ penderita diabetes melitus dengan kadar gula darah 2 jam sesudah makan diatas $180 \mathrm{mg} / \mathrm{dl}$ berkecenderungan 13,5 $\mathrm{x}$ lebih besar mengalami hambatan libido dibandingkan penderita dengan kadar gula. darah 2 jam sesudah makan dibawah $180 \mathrm{mg} / \mathrm{dl}$ yaitu 2 orang $(5 \%)$.

Berdasarkan hasil penelitian yang didapatkan dari beberapa informan bahwa sejak terdiagnosa menderita dibetes mellitus informan yang mengalami sekitar 5 dan 7 tahun 4 informan terdiagnosa tergolonng mudah di usia 37-47 tahun. dari rentang waktu terdiagnosa diabetes mellitus sepertinya tidak memakan waktu yang lama ahkirnya informan mengalami disfungsi seksual maksimal 5 tahun sudah didiagnosa menderita diabetes mellitus, waktu yang cukup pendek untuk informan mengalami kegagalan dalam disfungsi seksualnya yang akan membawah dampak pada kehidupan seksual secara keseluruhan.

Secara teori mengatakan dikatakan bahwa disfungsi seksual terjadi minimal 5 tahun setelah terdiagnosa diabetes dan bahkan $50 \%$ pria dengan diabetes akan mengalami disfungsi seksual ketika 10 tahun terdiagnosa (Lewis, 2001). Pada penelitian yang dilakukan oleh (Rachamdi, 2008). Didapatakan lama menderita diabetes mellitus dengan kemanpuan seksual. Semakin lama menderita diabetes mellitus maka semakin menurun kemanpuan seksualnya hambatan libido $58,3 \%$ pada klien dibawah 1 tahun, 73\% pada klien 1-5 tahun $85 \%$ pada diatas 5 tahun dan gangguan ereksi $58,3 \%$ pada klien dibawah 1 tahun $80 \%$ pada klien $1-5$ tahun $100 \%$ pada klien diatas 5 tahun. Hal ini sesuai dengan pendapat seorang ahli bahwa semakin lama menderita diabetes mellitus maka neuropati semakin jauh terjadi.

Keadaan ini dapat ditemukan pada laki-laki dengan sindrom Kleinefelter yang terganggu perkembangan testisnya akibat abrasi kromosom dengan mengakibatkan gagalnya produksi testoteron sehingga sering karakter yang ditemukan mereka memiliki dorongan seks yang rendah (Mueller, 2001).

\section{b. Gangguan Ejakulasi Dini}

Seiring dengan disfungsi seksual yang 2 informa yang mengalami ejakulasi dini baik cepat mengelurakan sperma sebelum coitus selesai sempurna atau jumlah sperma yang keluar sedikit sampai puas dan tidak berhubungan seks dalam waktu yang lama hanya berapa detik saja. 1 informan mengatakan 1-4 menit setelah ereksi maka sperma langsung keluar sebelum melakukan penetrasi atau sebelum dikehendaki dan 1 informan mengalami pada saat penis masuk dalam vagina hanya berapa menit langsung ejakulasi tidak merasa puas karena tidak adanya penetrasi yang terjadi sangat cepat membuat infroman merasa gelisah dengan keadaannya, hubungan seksual akhirnya dihentikan karena merasa tidak bergairah sehingga ereksi hilang, berbeda dengan lain 1 informan mengatakan hanya 2-4 kali goyang sedah ejakulasi. 
Menurut (Waldinger, 2008). Ejakulasi dini terjadi beberapa detik setelah penetrasi (pemasukan penis kedalam vagina) bahkan dapat terjadi pula sebelum penetrasi dilakukan. Kerusakan organ seksual terutama pada sistem syaraf karena adanya neuropathy perriver pada diabetes yang menyebabkan kurang sensitivitas saraf maupun zat yang mengatur ejakulasi sehingga terjadi ejakulasi dini.

Hasil penelitian 2 informan yang mengungkap bahwa ejakulasinya terhambat bahkan tidak terjadi ejakulasi sama sekali ketika melakukan hubungan intim dengan pasangannya. Hal ini disebabkan tidak terkoordinasinya rangsangan saraf yang mengalami neuropati. Pada beberapa informan mampu ereksi tapi tidak mampu untuk berejakulasi serta tidak merasakan puas karena tidak dapat mencapai orgasme dalam melakukan hubungan seksual. Dikuatkan Informasi yang didapatkan dari informan kunci bahwa diabetes tipe 2 merupakan suatu keadaan dimana terdapat kadar gula darah tinggi, konteks resisistensi insulin dapat mengakibatkan terhambat aliran pembuluh darah ke penis sehingga mengalami gangguan seksual seperti ejakulasi.

Ejakulasi terlambat (retrogade ejaculation): Merupakan ketidak mampuan mengalami ejakulasi dalam vagina dapat berupa primer yaitu tidak pernah mencapai ejakulasi dan sekunder yaitu sebelumnya pernah mencapai ejakulasi dengan normal, tetapi karena sebab tertentu mengalami hambatan ejakulasi dalam vagina (Pangkahila, 2005).

Ejakulasi dini merupakan disfungsi seksual yang banyak dijumpai di survei epidemiologik di Amerika serikat menunjukkan sekitar $30 \% \quad-70 \%$ pria mengalami ejakulasi di akibatkan oleh penyakit diabetes mellitus ejakulasi dini terjadi bentuk ejakulasi dini (premature ejaculation) : Adalah gangguan yang dikaitkan dengan kuantitas dari periode waktu aktifitas seksual laki-laki dengan kemampuan memasukkan penis ke vagina sebelum terjadi ejakulasi. Ejakulasi dini adalah ejakulasi yang terjadi sebelum penetrasi penis pada vagina atau setelah terjadi penetrasi singkat pada vagina (Perkeni, 2015).

Penelitian Waldinger pada tahun 2008 mendapatkan bahwa ejakulasi dini merupakan gangguan/ disfungsi seksual pria yang paling sering dijumpai. mempengaruhi sekitar 14-30\% pria berusia lebih dari 18 tahun, $30 \%-40 \%$ pria yang aktif secara seksual, dan $75 \%$ pria di saat tertentu di dalam kehidupannya.

\section{c. Disfungsi Ereksi}

Dalam penelitian ini 2 informan yang mengalami ereksi tidak maksimal Mereka membutuhkan rangsangan terlebih terdahulu untuk bisa sampai pada munculnya ereksi, waktu mulai ereksi lebih lama dari sebelum sakit sehingga membutuhkan upaya seperti rangsangan atau pemanasan (fore play) yang lebih lama, namun hal ini masih tidak maksimal bahkan tiba-tiba lemas. sehingga mengalami disfungsi ereksi tidak mampu mempertahankan ereksi lebih lama, beberapa menit secara tiba-tiba langsung lemas dan tidak bisa ereksi kembali.

Disfungsi ereksi pada penderita diabetes mellitus disebabkan oleh adanya gangguan pembuluh darah yang menuju kepenis. Ereksi terjadi apa bila rongga-rongga spongiosa pada penis terisi darah sehingga menjadi tegang. Hampir $>30 \%$ penderita diabetes laki-laki mengalami disfungsi ereksi. Ada 2 faktor yang menuntukan terjadinya ereksi yaitu Adanya rangsangan atau sensai seksual Keberadaan organ penis termaksuk pembuluh darah dan persarafan yang normal (Sutedjo,2010).

Berdasarkan hasil peneliti yang didapatkan dari 1 informan sulitnya untuk ereksi sehingga butuh upaya yang lebih dan bahkan terkadang muncul kegagalan dan merasa kondisi fisik yang tidak stabil, ini disebabkan karena tidak terkontrolnya gula darah sewaktu yang tinggi sekitar 320 $\mathrm{mg} / \mathrm{dL} \quad-450 \mathrm{mg} / \mathrm{dL}$ karena tidak mengatur pola makan. Selain ini disfungsi ereksi juga kuat dipengaruhi oleh kecemasan pada penderita diabetes tidak peduli dengan penyakitnya. Menurut (Basu \& Ruder, 2004) kadar glycosylate (HbA1c) merupakan independent predicator pada disfungsi ereksi.

Menurut penelitian Rachmadi (2008), Terdapat 29 orang $(72,5 \%)$ penderita 
diabetes mellitus yang mempunyai kadar gula darah puasa diatas $126 \mathrm{mg} / \mathrm{dl}$ mengalami disfungsi ereksi dengan kecenderungan 9,7 x lebih besar dibanding penderita dengan kadar gula darah puasa dibawah $126 \mathrm{mg} / \mathrm{dl}$, yaitu hanya 3 orang $(7,5 \%)$ Demikian pula dengan kadar gula darah 2 jam sesudah makan, terdapat 30 orang $(75 \%)$ penderita dengan kadar gula darah diatas $180 \mathrm{mg} / \mathrm{dl}$ mengalami disfungsi ereksi dengan kecenderungan 15 x lebih besar dibanding penderita dengan kadar gula darah 2 jam sesudah makan dibawah 180 $\mathrm{mg} / \mathrm{dl}$, yaitu hanya 2 orang $(5 \%)$.

Berbagi jenis gangguan pada disfungsi ereksi diatas dengan salah satu defenisi/kerusakan ereksi pada pria yaitu ketidak manpuan persisten atau berulang untuk mencapai atau mempertahankan ereksi sampai selesai aktivitas seksual (Rowlan, 2008)

Adapun hasil wawancara mendalam yang dilakukan pada informan pedukung mengungkapkan diperoleh bahwa hubungan seksual dengan suami menurun selama menderita diabetes mellitus sehingga tidak dapat mempertahankan ereksi itupun dibantu dengan untuk hubungan seks secara normal. Dan dari hasi wawancara informan kunci mengungkapakan bahwa diabetes mellitus tipe 2 merupakan suatu keadaan dimana terdapat kadar gula darah tinggi, konteks resisistensi insulin dapat mengakibatkan terhambat aliran pembuluh darah kepenis sehingga mengalami gangguan disfungsi seksual atau komplikasi berupa penyakit-penyakit kronis. Sesuai dengan teori yang dinyatakan oleh (Sutedjo, 2010) bahwa jika gula darah sewaktu meningkat maka akan menyebabkan terjadinya gangguan pembuluh darah sehingga menghambat aliran darah ke penis.

Hasil penelitian ini memberikan sebuah gambaran 4 informan yang mengalami penis cepat loyo ketika melakukan hubungan seksual, pada saat penis masuk ke dalam vagina dengan pasangannya hanya bertahan beberapa 5 menit saja sehingga tidak merasakan kepuasan, informan berusaha semaksimal untuk mempertahankan tetapi informan merasa tidak konsentrasi atau ketikan memulai hubungan intim dengan pasangannya merasa dirinya tidak mampu menpertahankan ereksi.

Menurut (Untung, 2010). Disfungsi ereksi disebabkan oleh faktor psikis dan fisik. Sikap yang tidak mendukung terhadap seksualitas, stres/depresi terutama, mitos, kurangnya pendidikan seksual, kecemasan, merupakan kumpulan faktor penggangu. Untuk faktor fisik terdiri atas faktor hormonal, gangguan pembulu darah atau syaraf, adanya komplikas penyakit lain pada tubuh, seperti kencing manis (diabetes), kolesterol tinggi, gangguan pada organ jantung atau ginjal, penyakit-penyakit, hipertensi (karena penggunaaan obat-obatan penurunan tekanan darah). Pada prinsip faktor-faktor ini menghalangi mekaniseme ereki sehingga penis tidak terjadi.

Disfungsi ereksi pada penderita diabetes juga dapat diketahui secara patofisiologi berdasarkan klasifikasi seluler bahwa terjadi berarapa perubahan pada tingkat seluler berhubungan dengan diabetes mellitus, yaitu kehilangan complain pada jaringan fibroelastic kelemahan pada channel maxi pada otot halus menurun membrane sel kontak sekunder nitric oxide pada endothelium ( Roland, 2008).

Berbagai jenis gangguan pada disfungsi ereksi diatas sesuai dengan salah satu defenisi gangguang/kerusakan ereksi pada pria yaitu ketidakmampuan penetrasi atau berulang untuk mencapai mempertahankan ereksi sampai selesai aktifitas seksual (Rowland, 2004).

Menurut Natasya, 2013 dari 30 sampel pria diabetes melitus didapatkan hasil bahwa diabetes melitus yang lamanya 1-4 tahun dengan kategori disfungsi ereksi ringan sebanyak 9 orang $(30 \%)$ dan pada kategori disfungsi ereksi ringan-sedang sebanyak 2 orang $(6,7 \%)$. Sedangkan pada diabetes melitus yang lamanya 5-8 tahun dengan kategori disfungsi ereksi ringan sebanyak 1 orang $(3,3 \%)$ dan pada kategori disfungsi ereksi ringan-sedang sebanyak 18 orang $(60 \%)$. Penelitian ini didapatkan bahwa diabetes melitus yang lama berhubungan dengan kejadian disfungsi ereksi. Kebanyakan disfungsi ereksi dialami pada penderita yang telah mengidap diabetes melitus lebih dari 5 tahun. Pada diabetes melitus yang lama dapat terjadi kelebihan 
gula darah atau gula darah yang tidak terkontrol, hal ini disebabkan karena ketidaksadaran dari pasien atau keterlambatan diagnosis karena kebanyakan pasien akan datang mencari pertolongan dari tenaga medis apabila penyakit mereka sudah parah. Sebagian dari orang-orang akan menyadarinya ketika sudah mengalami penurunan berat badan secara tiba-tiba dan beberapa gejala lainnya. Akibatnya gula darah dalam tubuh yang tidak terkontrol dapat merusak sel-sel saraf dan pembuluh darah.

\section{KESIMPULAN}

Disfungsi ereksi ketidak mampuan mempertahankan pada saat berhubungan seksual sehingga dapat terjadi penurunan cepat lemas ereksi tidak maksimal sehingga tidak dapat merasakan kepuasan. Gangguan ejakulasi dini yang dialami oleh informan ketika melakukan hubungan seksual secara cepat mengeluarkan sperma sebelum berhubungan dengan istri dan jumlah sperma yang kurang bahkan ada informan tidak mengeluarkan sperma ketika melakukan hubungan intim. ratarata informasi didapatkan dari informa kurang lebih dari 1 menit sudah ejakulasi. Gangguan Hasrat/libido dimana informan mengalami penurunan secara perlahanlahan sehingga keinginan, mood atau gairah untuk hubungan seksual tidak dapat terpeuhi.

Berdasarkan hasil penelitian ini maka peneliti menyarankan :

a. Diharapkan bagi penderita diabetes mellitus untuk melakukan pemeriksaan kesehatan secara komprehensif.

b. Pada penderita diabete mellitus sebaiknya rutin mengontrol gula darah sewaktu.

c. Diharapkan pada penderita diabetes memperhatikan gaya hidup sehat olah raga, mengatur pola makan untuk mencegah terjadi penyakit komplikasi.

\section{REFERENSI}

Anggraeni mekar dewi. Saryono. 2013. Metodologi Penelitian Kualitatif Dan Kuantitatif Dalam Bidang Kesehatan. Nuha
Medika. Yogyakarta.

Ansari Saleh, 2015. Perbedaan Kejadian Disfungsi Seksual Pada Wanita Dengan Diabetes Melitus Dan Tanpa Diabetes Melitus. Jurnal Berkala Kedokteran Vol.12 Banjarmasin.

Aris Muhammad.S, 2016. Hubungan Disfungsi Ereksi Pada Penderitadiabetes Mellitus Tiype 2 Terhadap Kualitas Hidup Di Polikilinik Penyakit Dalam Rsup Sanglah Provinsi Bali. EJurnal medika vol.5 No. 5. Bali

Baldwin Dorothy. 2016. Panduan Kesehatan Pria dari seksual Hingga Manajemen Stres Cetakan I. Nansa. Bandung.

Benvie. 2016. Menjelejai dunia dengan sejuta pertanyaan.

Basu A.Ryder, R.E.J, 2004. New Tertment Options For Erectile Dysfunction In Patients With Dysfunction In Patients With Diabetes Mellitus. Revew Artikel on Drung.

Chris. Tato. 2014. Kapita Selekta Kedokteran Jilid II. Media Aesculapius. Jakarta.

Conway J.R.C, Pacaud D. An Undisclosed Affair. 2010. Sexual Dysfunction in Diabetes. Canada: Canadian Diabetes Association.

Corwin, Elizabeth J. 2009. Buku Saku Patofisiologi Edisi 3. Jakarta: Penerbit Buku Kedokteran EG)

Dune, T.M \& Shuttlewort, R.P. 2009. It's Just Supposed To Happe": The Myth Of Sexual Spontaniteity And The Sexually Marginalized.

Dunning Trisha. 2013. Care Of People With Diabetes. A Manual Of Nursing Practice, $4^{\text {th }}$. Wiey Blackwell.

Dunning T. 2003. Care Of People With Diabetes. A Manual Of Nursing Practice. USA. Blackwell Publishing.

Diabetes UK.2009. Men And Sexual Dysfuncation.

Eardley I, Sethia K. 2000. Erectile Disfunction Current Investigation And Management. Mosby 
Wolfe. London.

Escadon JC. Cipolla M. 2011. Diabetes And Endothelial Dysfuncation: A Clinical Perpective. The Endocrine Society.

Gunawan,I.2015. Metode Penelitian Kualitatif : Teori Dan Praktik. Bumi Aksara : Jakarta

Ganong. 2015. Buku Ajaran Fisiologi

Kedokteran Edisi 22. ECG. Jakarta

Hidayat. A.A.2014. Metode Penelitian

Kebidanan Dan Teknik Analis, Salemba

Medika, Jakarta Selatan.

Jacobs LI. 2005. Impotensi Yang Perlu Diketahui Setiap Suami Istri. Pustakan Sinar Harapan. Jakarta.

Lim KB, Brock GB . 2006. Sexual Dysfunction in Men with Diabetes. Canadian Diabetes Association. Canada.

Lewis, R.w.2003. Epiemologi Of Erectile Dysfucation. Urologic Clinice If Nort Amerika.

Muller RF, Young ID. 2001. Emery's Elements Of Medical Genetics. Edinburg London. Churchill Livingstone.

Mccarty,B.W,D.K. Metz, M.E, 2008. Men's Sexual Health Fitness For Satisfying Sex. New York. Routledge. Tylor \& Francis Group.

Natasya J. dodie, 2013. Pengaruh Lamanya Diabetes Mellitus Terhadap Kejadian Disfungsi Ereksi. Jurnal-e biomedik (eBM0 Volume 1 nomor 3. Manado

Odendaal, HJ. Schaetzing,A.E., Kruger. T.F. 2008. Contraception And Sexuality Healt And Disease. USA. Sapire in Clinical Gynaecology.

Pusat Data Informasi Kementrian Kesehatan RI. 2014.

Profil Dinkes Kota Makassar tahun 2015

Perkini . 2015. Consensus Pengolahan Diabetes Mellitus Tipe 2 Di Indonesia. Semarang.

Purnomo BB.2014. Dasa-Dasar Urologi Edis 3. CV Sagung seto. Jakarta
Pangkahila, W. 2012. Tetap Sehat Sehat Dan Mudah Dengan Konsep Anti-Aging Medicine Kehidupan Yang Harmonis. Naska Seminar Fakultas Kedokteran Unizar. Mataram

Pangkhahila W. 2005. Menguak disfungsi ereksi menyimak Masalah Pria Keluhan wanita. PT Gramedia. Jakarta.

Penson DF, Wessells H. 2004. Erectile Dysfuncation In Diabetic Patients. America Diabetis Association.

http://spectrum.dabetesjornals.orang/contet/17/4 /231.full-text.pdf.

Ridwan Harahap, 2006. Disfungsi Seksual Pada Penderita Diabetes.jurnal kedokteran volume 39 no 3 . USU

Rowland, D.L. \& Incrocci, L. 2008. Handbook of sexual and gender identity disorders. Hokoben, new Jersy. John Wiley \& Sons,Inc.

Russel ST.dkk. 2014. Erecil Dysfunction And Cardiovaskuler Diases. Rochenster. Min.

Rachmadi, A. 2008.Kadar Gula Darah Dan Kadar Hormone Testeron Pada Pria Penderita Diabetes Mellitus Hubungan Dengan Seksual Dan Perbedaan Dengan Yang Tidak Memgalami Disfungsi Seksual . Universitas Dipenogoro Semarang.

Sugiona. 2012. Metode penelitian kuantitaif,kualitatif R \& D. Alfabeta : Badung.

Suprapto S.I. Hasdianah HR. 2014. Patologi Dan Fisiologi Penyakit. Nuha Meedika. Yogyakarta

Sutedjo. A.Y. 2010. 5 Strategi Penderita Diabetes Mellitus Berusia Panjang 028266. Kanisius. Yogyakarta.

Sukawan UY. 2002. Gangguan Seksual Pada Pria Diabetes Mellitus. Dalam Pertemuan Ilmiah Tahunan XIV Perkumpulan Andrology Indonesia Dan Kongres Nasional I Asosiasi Sexology Indonesia. Denpasar.

Sutedjo. A.Y. 2010. 5 Strategi Penderita Diabetes Mellitus Berusia Panjang 028266. Kanisius. Yogyakarta.

Solomon, H, Man J.W. 2003. Erectile 
dysfunction : Cardiovasculer risk and the role of the cardiologist. Internasion jornul. Clinical Practice.

Tajokonegoro. A, Muetiani AS. 2003. Rahasia Diballik Keperkasaan Pria. Jakarta. FKUI.

Hasdianah H.R. 2012. Mengenal Diabetes Mellitus Cetakan I. Nuha Medika. Yogyakarta. Alfa Beta, Bandung.

Hanash, K.A. 2008. New Frontiers In Men's Sexual Healt. Understanding Erectile Disfunction And The Revolationnary New Treatments. Westport Connecticut. Landon.

Irianto koes. 2014. Seksologi Kesehatan Cetakan pertama. Alfabeta. Bandung.

Untung. 2010. Disfunsi Ereksi: Gangguan Sexsual Pria. Pengobatan Tradisional Notes.

Widyanto faisalado Candra \& Triwibowo Cecep. 2013. Trend Disease. CV. Trans Info Media. Jakarta.

Waldinger, M.D. 2008. Prematur Ejaculatiaon : Pathophysiologies And Etiologies Determine Its Treatment. Jurnal Of Sex And Maritial Therapy.

Wild S, Roglic G, Green A, Sicree R, King H. 2014 Global Prevalence of Diabetes: Estimates for the Year 2000 and Projections for 2030. Scotland: Diabetes Car 


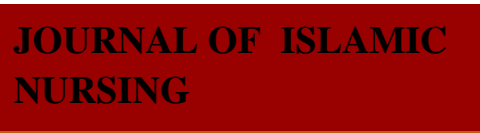

